\title{
No beta cell desensitisation after a median of 68 months on glibenclamide therapy in patients with $K C N J 11$-associated permanent neonatal diabetes
}

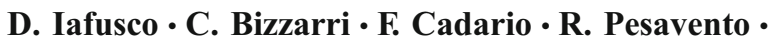 \\ G. Tonini $\cdot$ S. Tumini $\cdot$ V. Cauvin $\cdot$ C. Colombo $\cdot$ \\ R. Bonfanti $\cdot$ F. Barbetti
}

Received: 28 April 2011 /Accepted: 18 July 2011 /Published online: 7 August 2011

(C) Springer-Verlag 2011

Keywords Chronic · Durability Efficacy · Glibenclamide . KCNJ11 gene $\cdot$ Kir6.2 $\cdot$ Mutations $\cdot$ Permanent neonatal diabetes $\cdot$ Sulfonylurea $\cdot$ Therapy

\section{Abbreviations \\ DEND Developmental delay, epilepsy and neonatal diabetes \\ iDEND Intermediate DEND}

To the Editor: Patients with permanent neonatal- or infancy-onset diabetes mellitus associated with activating mutations of KCNJ11 and $A B C C 8$ genes, which encode

D. Iafusco

Department of Paediatrics, Second University of Naples, Naples, Italy

\section{Bizzarri}

Endocrine Unit, Bambino Gesù Children's Hospital, IRCCS, Rome, Italy

F. Cadario

Department of Paediatrics, University of Eastern Piedmont, Novara, Italy

R. Pesavento

Paediatric Unit, Boldrini Hospital,

Thiene, Italy

\section{G. Tonini}

Institute for Maternal and Child Health-IRCCS "Burlo Garofolo", Trieste, Italy the ATP-sensitive potassium channel of the pancreatic beta cell, can be successfully weaned from insulin and transferred to sulfonylureas $[1,2]$. Individuals carrying specific mutations of $K C N J 11$ or $A B C C 8$ may present with developmental delay, epilepsy and neonatal diabetes (DEND) syndrome or intermediate DEND (iDEND), i.e. may have, in addition to diabetes, motor/mental developmental delay with or without epilepsy. Notably, patients with DEND may require higher doses of sulfonylureas to attain proper metabolic control [3]. Glibenclamide, a long-acting sulfonylurea largely used in the therapy of type 2 diabetes, is often used to treat patients with neonatal- or infancy-onset diabetes due to KCNJ11 or $A B C C 8$ mutations [1-4].

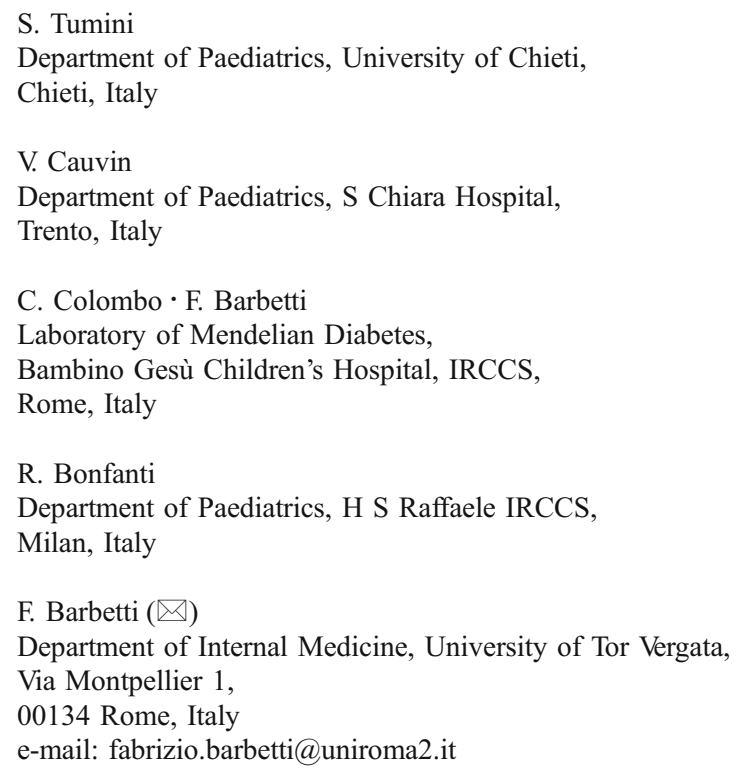


However, about $50 \%$ of type 2 diabetic patients treated with glibenclamide experience a severe deterioration of metabolic control (fasting plasma glucose $>15 \mathrm{mmol}$ ) within 6 years of therapy initiation [5]. This phenomenon, known as 'sulfonylurea secondary failure', may derive from a loss of insulin secretory capacity due to hyperexcitability of pancreatic beta cells chronically exposed to sulfonylureas [6]. The aim of the present study was to verify the efficacy of chronic glibenclamide therapy in patients with a form of diabetes resulting from activating mutations of $K C N J 11$.

In the period 2004 to 2010,27 of our patients who had permanent neonatal- or infancy-onset diabetes due to an activating $K C N J 11$ or $A B C C 8$ mutation were switched to sulfonylureas. In the present investigation, we examined 11 patients who are carriers of a KCNJ11 mutation (Table 1), were diagnosed with diabetes between 2004 and 2006, and have been free of insulin and on glibenclamide for more than 57 months (ten for $\geq 5$ years). In this group, six of the 11 patients presented with iDEND (mutations G53D, V59M, R201C) and one with the complete DEND syndrome (mutation V59A); ten were prepubertal and one was an adult [7] at the time of the medication 'switch' (Table 1). Informed consent was given by the adult participant or by parents; the study was conducted in accordance with the Declaration of Helsinki as revised in 2000 (http://www.wma.net/e/policy/b3.htm).

The insulin dose and $\mathrm{HbA}_{1 \mathrm{c}}$ before the switchover, as well as the glibenclamide dose and $\mathrm{HbA}_{1 \mathrm{c}}$ at 3 and 68 months (median) after insulin weaning were recorded. Student's $t$ test was used to compare $\mathrm{HbA}_{1 \mathrm{c}}$ values before and after glibenclamide. Two polymorphisms of $C Y P 2 C 9$ (R144C and I359L), which may affect glibenclamide metabolism, were genotyped by restriction-fragment length polymorphism PCR [8].

$\mathrm{HbA}_{1 \mathrm{c}}$ at baseline was $8.4 \pm 0.86 \% \quad($ mean $\pm \mathrm{SD}$; $68 \mathrm{mmol} / \mathrm{mol})$ and decreased to $5.9 \pm 0.92 \%(41 \mathrm{mmol} / \mathrm{mol})$ after 3 months of glibenclamide therapy ( $p=1 \times 2.05^{-6}$ vs basal). At that time, the mean glibenclamide dose was $0.47 \pm 0.22 \mathrm{mg} \mathrm{kg}^{-1}$ day $^{-1}$ in the nine pre-pubertal patients with isolated diabetes or iDEND, $0.8 \mathrm{mg} \mathrm{kg}^{-1}$ day $^{-1}$ in the adult patient with iDEND (mutation G53D) and $1.75 \mathrm{mg} \mathrm{kg}^{-1}$ day $^{-1}$ in the patient with complete DEND (mutation V59A). No relationship between glibenclamide dose and insulin dose before switchover was observed. At 68 months (median) after transfer, mean $\mathrm{HbA}_{1 \mathrm{c}}$ was $6 \pm 0.39 \%$ (42 $\mathrm{mmol} / \mathrm{mol} ; p=1 \times 10^{-9}$ vs basal) with glibenclamide doses of $0.12 \pm 0.05 \mathrm{mg} \mathrm{kg}^{-1} \mathrm{day}^{-1}$ in the nine pre-pubertal patients with simple diabetes or iDEND, $0.47 \mathrm{mg} \mathrm{kg}^{-1}$ day $^{-1}$ in the 32-year-old patient with $K C N J 11 / \mathrm{G} 53 \mathrm{D}$ and $0.87 \mathrm{mg} \mathrm{kg}^{-1} \mathrm{day}^{-1}$ in the patient with DEND (Table 1). The glibenclamide dosage recorded at the last visit in the latter two patients was approximately 2 - and 3.5 -fold the maximum glibenclamide dose used in a typical patient with type 2 diabetes $(20 \mathrm{mg} /$ day in a patient weighing $80 \mathrm{~kg}$, i.e. $0.25 \mathrm{mg} \mathrm{kg}^{-1}$ day $^{-1}$ ). Interestingly, the mean glibenclamide dose was slightly higher in three patients with mutation $\mathrm{R} 201 \mathrm{H}$ and isolated diabetes than in four patients who had iDEND associated with mutation V59M (R201H $0.13 \mathrm{mg} \mathrm{kg}^{-1}$ day $^{-1}$ vs V59M $0.09 \mathrm{mg} \mathrm{kg}^{-1}$ day $^{-1}$ ). No difference in CYP2C9 genotypes was observed between these two groups.

Table 1 Glibenclamide dose and duration in 11 patients with permanent neonatal diabetes associated with a mutation of $K C N J 11$

\begin{tabular}{|c|c|c|c|c|c|c|c|c|c|}
\hline \multicolumn{3}{|c|}{ Patient details } & \multirow[t]{2}{*}{$\begin{array}{l}\text { Insulin dose before switch } \\
\text { over }\left(\mathrm{U} \mathrm{kg}^{-1} \text { day }^{-1}\right)\end{array}$} & \multirow[t]{2}{*}{$\begin{array}{l}\text { Current dose } \\
\left(\mathrm{mg} \mathrm{kg}^{-1} \text { day }^{-1}\right)\end{array}$} & \multirow[t]{2}{*}{$\begin{array}{l}\text { Frequency } \\
\text { (times per day) }\end{array}$} & \multirow[t]{2}{*}{$\begin{array}{l}\text { Duration } \\
\text { (months) }\end{array}$} & \multicolumn{2}{|c|}{$\begin{array}{l}\mathrm{HbA}_{1 \mathrm{c}} \text { at } \\
\text { last visit }\end{array}$} & \multirow[t]{2}{*}{$\begin{array}{l}\text { DEND } \\
\text { status }\end{array}$} \\
\hline Number & $\begin{array}{l}\text { KCNJ11 } \\
\text { mutation }\end{array}$ & $\begin{array}{l}\text { Age at follow-up } \\
\text { (years, months) }\end{array}$ & & & & & $\%$ & $\mathrm{mmol} / \mathrm{mol}$ & \\
\hline $1^{\mathrm{a}}$ & G53D & 32 & 1.08 & 0.47 & 4 & 57 & 6.4 & 46 & iDEND \\
\hline 2 & V59M & 7,5 & 0.6 & 0.06 & 3 & 70 & 6.3 & 45 & iDEND \\
\hline 3 & V59M & 8,10 & 0.9 & 0.14 & 3 & 79 & 6.4 & 46 & iDEND \\
\hline 4 & V59M & 15,7 & 0.9 & 0.08 & 4 & 78 & 5.4 & 35 & iDEND \\
\hline 5 & V59M & 11,5 & 0.6 & 0.08 & 3 & 61 & 6.4 & 46 & iDEND \\
\hline $6^{\mathrm{a}}$ & V59A & 6,1 & 0.4 & 0.87 & 2 & 60 & 5.5 & 36 & DEND \\
\hline 7 & K170R & 13,6 & 0.6 & 0.17 & 3 & 60 & 6.2 & 44 & No \\
\hline 8 & $\mathrm{R} 201 \mathrm{H}$ & 6,3 & 0.8 & 0.16 & 3 & 69 & 5.6 & 37 & No \\
\hline 9 & $\mathrm{R} 201 \mathrm{H}$ & 6,3 & 0.5 & 0.17 & 3 & 68 & 5.7 & 38 & No \\
\hline 10 & $\mathrm{R} 201 \mathrm{H}$ & 7,5 & 0.55 & 0.05 & 3 & 66 & 5.8 & 39 & No \\
\hline 11 & R201C & 8,2 & 0.3 & 0.16 & 2 & 76 & 6.2 & 44 & iDEND \\
\hline
\end{tabular}

${ }^{a}$ Patients on high dose of glibenclamide 
Episodic, short-lived diarrhoea in the first week of treatment was the only side effect observed during the entire period of treatment.

Previously, others have reported the efficacy of sulfonylurea (glibenclamide, glipizide) use for up to 34 months in a limited number of patients with permanent neonatal diabetes mellitus due to KCNJ11 mutations [9, 10]. Here we show that chronic glibenclamide therapy retains its efficacy for a long period of time in patients with neonatal- or infancy-onset diabetes associated with KCNJ11 gene mutations. Notably, the sulfonylurea dose was progressively reduced in all cases, and in the nine prepubertal patients with simple diabetes or iDEND, the daily dose of glibenclamide per $\mathrm{kg}$ body weight at the last visit was comparable with the dosage commonly used in patients with type 2 diabetes. This result indicates that, in contrast to observations during chronic glibenclamide treatment in normal mice [6], beta cell desensitisation does not occur in patients with diabetes due to KCNJ11 mutations. In addition, the long-standing, optimum metabolic control obtained in two patients (patient 1 [an adult patient] and patient 6 [a DEND patient]) treated with high doses of glibenclamide for more than 57 and 60 months, respectively (Table 1), suggests that no deterioration of their beta cell mass has occurred.

Our data therefore reinforce the notion that the decrease of glibenclamide efficacy observed in a high percentage of patients with type 2 diabetes [5] may reflect the natural evolution of the disease in individual patients, rather than a specific effect of the drug. Nevertheless, it should be noted that the pathophysiology of hyperglycaemia and the (relative) beta cell failure observed in patients with type 2 diabetes is strikingly different from that in individuals with neonatal- or infancy-onset diabetes due to KCNJ11 mutations. In this respect our study was not able to address the question of whether sulfonylurea treatment may have deleterious effects on the beta cell when patients also have insulin resistance and abnormal levels of circulating NEFA, as is often the case with type 2 diabetes. In addition, although ours is the largest sample ever reported of patients with permanent neonatal diabetes associated with $K C N J 11$ mutations to receive chronic glibenclamide therapy, our number of participants is nevertheless small, and we cannot exclude the possibility that glibenclamide therapy may fail at some point in these or other patients weaned from insulin.

In conclusion, chronic glibenclamide treatment appears to be safe and efficacious over time in patients with neonatal- or infancy-onset diabetes associated with mutations of the KCNJ11 gene.

Acknowledgements Part of this work has been supported by the Fondazione Roma grant 'Molecular mechanisms in the pathogenesis of type 2 diabetes mellitus and its cardiovascular complications' to F. Barbetti.

Contribution statement DI, CB, FC, RP, GT, ST, VC, CC and RB researched, analysed and interpreted data, revised the article and gave final approval of the version to be published. FB conceived and designed the study, analysed data, draft the article and gave the final approval of the version to be published.

Duality of interest The authors declare that there is no duality of interest associated with this manuscript.

\section{References}

1. Pearson ER, Flechtner I, Njolstad PR et al (2006) Neonatal Diabetes International Collaborative Group. Switching from insulin to oral sulfonylureas in patients with diabetes due to Kir6.2 mutations. N Engl J Med 355:467-477

2. Tonini G, Bizzarri C, Bonfanti R et al (2006) Sulphonylurea treatment outweighs insulin therapy in short-term metabolic control of patients with permanent neonatal diabetes mellitus due to activating mutations of the KCNJ11 gene. Diabetologia 49:2210-2213

3. Shimomura K, Horster F, de Wet $\mathrm{H}$ et al (2007) A novel mutation causing DEND syndrome: a treatable channelopathy of pancreas and brain. Neurology 69:1342-1349

4. Rafiq M, Flanagan SE, Patch A-M, Shields BM, Ellard S, Hattersley AT (2006) Effective treatment with oral sulfonylureas in patients with diabetes due to sulfonylurea receptor 1 (SUR1) mutations. Diabetes Care 31:204-209

5. Matthews DR, Cull CA, Stratton IM, Holman RR, Turner RC (1998) UKPDS 26: sulphonylurea failure in non-insulin dependent diabetic patients over six years. UK Prospective Diabetes Study (UKPDS) Group. Diabet Med 15:297-303

6. Remedi MS, Nichols CG (2008) Chronic sulfonylureas in vivo: reversible effects on mouse pancreatic $\beta$-cells. PLoS Med 5:e206

7. Koster JC, Cadario F, Peruzzi C, Colombo C, Nichols CG, Barbetti F (2008) The G53D mutation in Kir6.2 (KCNJ11) is associated with neonatal diabetes and motor dysfunction in adulthood that is improved with sulfonylurea therapy. J Clin Endocrinol Metab 93:1054-1061

8. Kirchheiner J, Brockmoller J, Meineke I et al (2002) Impact of CYP2C9 amino acid polymorphism on glyburide kinetics and on insulin and glucose response in healthy volunteers. Clin Pharmacol Ther 71:286-296

9. Klupa T, Sklupien J, Sieradzka B et al (2010) Efficacy and safety of sulfonylurea use in permanent neonatal diabetes due to KCNJ11 mutations: 34-month median follow-up. Diabetes Technol Ther 12:387-391

10. Vendramini MF, Gurgel LC, Moises RS (2010) Long-term response to sulfonylurea in a patient with diabetes due to mutation in the KCNJ11 gene. Arq Bras Endocrinol Metab 54:682-684 